\title{
Health Needs and Self Efficacy for Rheumatoid Arthritis Patients
}

\author{
Mennatallah Helmy Mossad Seyam, Dina El Tabey Sobeh, Shereen Ahmed Qalawa \\ Demonstrator at Faculty of Nursing - Port-Said University, Lecturer of Medical \\ Surgical Nursing - Faculty of Nursing - Port-Said University, Assistant Professor of \\ Medical Surgical Nursing - Faculty of Nursing - Port-Said University
}

\begin{abstract}
Background: Rheumatoid arthritis (RA) is a chronic inflammatory autoimmune disease that greatly impacts all aspects of health-related quality of life, including physical, emotional, social and spiritual. Aim: This study aimed at assessing health needs and self efficacy for rheumatoid arthritis patients. A descriptive research design was conducted. Setting: At rheumatology outpatient clinics at Port-Said general hospital and Port-Fouad general hospital which are affiliated to the Ministry of Health in Port-Said governorate. A convenient sample of 50 adult rheumatoid arthritis patients was included in the study. Tools of data collection: Tool (1) A Structured Interview consisted of two parts- a) Socio-demographic characteristics and medical history-b) Health Needs Questionnaire. Tool (2) Arthritis Self-Efficacy Scale (ASES). Results: More than half of study patients have health needs. The highest needs are in relation to psychological needs; then physical needs; then educational needs. The lowest needs are in relation to social and spiritual needs. Also, most of patients have high self-efficacy and there is statistically significant negative relation between health needs of RA patients and their self-efficacy. Conclusion: More than half of RA patients have health needs, although most of them have high self-efficacy. The highest needs are in relation to psychological needs, then physical needs, then educational needs, while the lowest needs are in relation to social and spiritual needs. Recommendations: Further study for assessment of factors influencing health needs and self-efficacy of RA patients.
\end{abstract}

Key Words: Health Needs, Patients, Rheumatoid arthritis, Self-Efficacy. 


\section{INTRODUCTION}

Rheumatoid arthritis is a chronic autoimmune systemic inflammatory disease of unknown cause affecting many tissues and organs but principally targets the synovial lining of the joints leading to peripheral symmetrical inflammatory polyarthritis (Ferri, 2017). RA attacks approximately $0.5 \%$ to $1 \%$ of the world population, with predominance of 2-3 times more in females. It affects all age groups, but is more prevalent among 40-60-year people. In rural Egypt, a prevalence of up to 0.3\% was found in the adult population (Smolen et al., $2016 \&$ Usenbo et al., 2015).

Clinical onset of RA may be variable; it generally begins with symmetrical involvement of the small joints, pain, morning stiffness, and limitation of movement for more than 1 hour. Although the meta-carpophalangeal (MCP) joints, the proximal interphalangeal (PIP) joints, the wrists, the metatarsophalangeal (MTP) joints and the knee joints are the most frequently involved joints, RA may also involve other ones (Almeida et al., 2014).

Rheumatoid arthritis patients face an increased mortality risk, largely as a result of cardiovascular disease. Specifically, rheumatoid arthritis patients have a higher incidence of myocardial infarctions and congestive heart failure because of the chronic inflammatory nature of RA and the increased prevalence of atherosclerosis in this population. Rheumatoid arthritis is associated with other serious co morbidities, including infection, osteoporosis, lymphoma, Felty syndrome, vasculitis, and peptic ulcer disease (often as a result of nonsteroidal anti-inflammatory drug (NSAID) treatment. In addition to physical limitations, patients with RA can experience social and emotional impairments and disabilities. Many RA patients report impaired psychological and social functioning, depression and reduced ability to participate in gainful employment. Individuals with RA also experience diminished quality of life relative to those without RA (Lesko et al., 2010).

Health needs are defined as "the requirements of individuals to enable them to achieve, maintain, or restore an acceptable level of social independence or quality of life (Carlsson et al., 2010). Assessment of RA patients' needs is crucial to enable the development of better healthcare services and contribute towards a more holistic care 
of RA patients, which will ultimately improve the QoL of these patients (Zuidema et al., 2015).

Self-efficacy (SE) refers to the belief in one's capabilities to organize and execute the courses of action required to manage prospective situations. More simply, it is what an individual believes he or she can accomplish using his or her skills under certain circumstances. Self-efficacy is predictive of motivation levels, thought patterns, moods, emotional reactions, and attitudes that can mediate the capacity and willingness to elicit behaviors that promote health (Sperber et al., 2014). Because it is fundamental to many health-related behaviors and practices, self-efficacy is likely to be of immense importance in the context of influencing health outcomes among RA patients. This is not only because self-efficacy predicts the amount of effort and perseverance expended in reaching a goal, but it specifically influences the selection of goal-directed behaviors, in addition to the development of realistic goals (Larkin \& Kennedy, 2014).

\section{SIGNIFICANCE OF THE STUDY:}

Rheumatoid arthritis is a chronic often disabling form of inflammatory arthritis. The impact of RA is reduction of patients' daily activities. As RA follows patients for their entire lives, a severe condition leads to disability and eventually affects patients' education, work, family life and social activity. Thus, the disease is not only affects patients' quality of life, but also increases the cost of care, resulting in a financial burden for society and the patient's family. Management of RA involves treatment from a range of healthcare providers over many years as well as selfmanagement by the person affected (Brand et al., 2010 \& Lee et al., 2010). Because of the far-reaching impacts of RA on the physical, psychological, social, and spiritual aspects of patients' lives, it is important for nurses to have insight in RA patients' health needs with considering the perspectives of these patients to deliver effective interventions tailored to these needs (Zuidema et al., 2015).

There is an increasing awareness that RA symptoms are influenced by psychosocial factors such as self- efficacy (SE), which is thought to be associated with self-management behavior and thus to affect the course of the disease (Primdahl et al., 2011), therefore assessment of self efficacy of RA patients will help identify 
specific problem areas that need special attention. So, there is a necessary need to conduct this study to assess health needs and self-efficacy of rheumatoid arthritis patients.

\section{AIM OF THE STUDY:}

This study aimed at assessing health needs and self-efficacy for rheumatoid arthritis patients.

\section{it will be achieved through the following:}

- Assess health needs for rheumatoid arthritis patients.

- Assess self efficacy for rheumatoid arthritis patients.

\section{SUBJECTS AND METHOD:}

A descriptive research design was utilized in this study.

\section{Study setting:}

This study was conducted at rheumatology outpatient clinics at two hospitals affiliated to the Ministry of Health in Port-Said governorate (Port-Said General Hospital and Port -Fouad General Hospital).

\section{Study subjects:}

A convenient sample, which consisted of 50 adult patients diagnosed with rheumatoid arthritis, was included in the study.

\section{Tools of data collection:}

Two tools were used in data collection:

\section{Tool I: Structured Interview}

This tool was adapted from (Hurlbert, 2002 \& Mohamed, 2012) to assess health needs of rheumatoid arthritis patients. Some modifications were done based on the reviewing literature and translated into Arabic language. 
It consisted of two parts:

\section{Part (1): Socio-demographic characteristics and medical history}

This part composed of 21 items as the following:

I. Socio-demographic characteristics: included gender, age, job, level of education, marital status, residence area, family income and treatment payment system.

II. Medical history: included patient's history, family history of rheumatoid arthritis, signs and symptoms of disease.

\section{Part (2): Health Needs Questionnaire}

This part included five dimensions:

I. Physical needs: included 49 items related to rest and sleep, eating, mobility, body care "personal hygiene", wearing clothes "dressing", household chores for female patients, holding and gripping "hand activities", work outside home for employed patients, exercise, sexual relation, and prescribed medications.

II. Psychological needs: included five items to assess (mood swings "anxiety / fear / sadness", feeling of distress without reason...etc).

III. Social needs: included six items (decreased visits to friends and relatives, decreased participation in social activities...etc).

IV. Spiritual needs: included three items (disease is a punishment from god, an expiation of sins or a test from god).

V. Educational needs: included four items (does your rheumatologist answer all your questions?, if yes; what do you need to ask for the following "causes of disease, clinical manifestations, medications, treatment options and cost, follow up...etc"?, you have other sources for meeting your educational needs?, and if yes; which of the following "internist, nurse, rheumatology books, mass media...etc"?

\section{Scoring system of tools:}

\section{A) Scoring system of Health Needs Questionnaire}

The respondent was asked for each item to explore if there was a health need requiring to be met. Items are scored on a three-point likert scale dividing in: 0 (never or low need), 1 (sometimes or moderate need), and 2 (always or high need). The higher scores indicated higher needs. The total score percentage was classified as the 
following: $>66.7 \%$ (high needs), from $33.3 \%$ to $66.7 \%$ (moderate needs), and < 33.3\% (low needs) (Mohamed, 2012).

\section{B) Scoring system of Arthritis Self-Efficacy Scale}

Items were rated on a 1 (very uncertain) to 10 (very certain) rating scale. The score for each item was the number circled. The score for the scale was the mean of the eight items. The higher scores indicated a higher degree of self-efficacy. The total score percentage was classified as the following: $\geq 50 \%$ (high self-efficacy) and $<$ $50 \%$ (low self-efficacy).

\section{Tool II: Arthritis Self-Efficacy Scale (ASES)}

This tool was adapted from (Lorig et al., 1989), to assess self-efficacy for rheumatoid arthritis patients or patients' belief that they could perform specific tasks or behaviors to cope with the consequences of rheumatoid arthritis. It consisted of eight items in three subscales: self-efficacy for managing pain, two items; selfefficacy for controlling other symptoms, four items; and self-efficacy for preventing pain and fatigue from interfering with daily activities, two items. ASES was translated into Arabic language and then retranslated to English language to ensure the right or accurate translation.

\section{Content validity \& Reliability:}

Content validity of both tools was tested by nine experts from Faculty of Nursing in the field of medical-surgical nursing (5) and community health nursing (1), as well as rheumatologists from Faculty of Medicine (3). The tools were modified according to the experts' comments and recommendations. Also, both tools were tested for reliability using Cronbach's alpha that was for Health Needs Questionnaire $=0.920$ and for Arthritis Self-Efficacy Scale $=0.995$.

\section{Pilot study:}

A pilot study was carried out on $10 \%$ of the study sample (five patients) who were then excluded from the sample to test the feasibility and applicability of tools and estimate the time required to fill in them. It was conducted over a period of one month before embarking on the field work of the study.

\section{Field work:}

Data were collected by the researcher using the study tools through an individualized interview with each patient that lasted between 20 and 30 minutes. The researcher visited the selected settings for the purpose of collecting data in the morning 
shift for three days per week in a period of six months from October $1^{\text {st }} 2015$ to March $31^{\text {st }}$ 2016.

\section{Ethical consideration:}

An approval to conduct the study at the study settings was taken from directors, rheumatologists, and nurses after the researcher explained the aim of this study. Verbal consent was obtained from each patient to be included in the study after explaining the aim of this study and the importance of his / her participation, as well stressing on confidentiality of the collected information. The researcher emphasized that the participations are absolutely voluntary and each patient has the right to withdraw from the study at anytime without explaining any reasons. The process of data collection did not disturb the harmony of the work, in other words, all collected data from the study subjects were only used for the purpose of the study and were processed in a total confidentiality.

\section{Statistical analysis:}

Data entry and statistical analysis were done using statistical package for social sciences (SPSS) version 20.0. Data were presented using descriptive statistics in the form of frequency, percentages, means, and standard deviations. Categorical variables were compared using Chi-square test; Fisher's Exact, and Monte Carlo correction for chi-square when more than $20 \%$ of cells have expected count less than 5 . In addition, Pearson coefficient test was used to correlate between health needs and self-efficacy for rheumatoid arthritis patients at Port-Said governmental hospitals.

\section{RESULTS:}

Table (1): clarifies that $90 \%$ of study patients were females, $28 \%$ of them were at age group $40-<50,64 \%$ of them were housewives, $36 \%$ of them got secondary education, $82 \%$ were married, all of them (100\%) were from urban area, $66 \%$ of them had not enough family income and $40 \%$ of them were patient expense as treatment payment system.

Table (2a): illustrates that $48 \%$ of study patients had $>5$ years duration of disease, $96 \%$ of them detected the disease by suffering from symptoms, $64 \%$ of them suffer from other chronic diseases whereas $68.8 \%$ of them suffer from hypertension, $18.8 \%$ suffer from cardiovascular diseases, and 15.6\% suffer from diabetes mellitus and liver 
diseases; for rheumatoid treatment, $86 \%$ of patients took medications, $90 \%$ of patients were adherent to medications, and $78 \%$ of patients had not family history of disease; for patients with family history of disease, $36.4 \%$ of them had second degree relatives with the same disease and $81.1 \%$ of them reported "improved" as disease prognosis in family.

Table (2b): illustrates that, for articular manifestations, all patients (100\%) reported joints pain; for extra - articular manifestations, $84 \%$ of them reported difficulty in performing activities of daily living; and for medications' side effects, $50 \%$ of them reported heart burn, 34\% reported weight gain, and 22\% reported constipation.

Table (3): illustrates that the study patients have high psychological needs (48\%); moderate physical and educational needs (54\% and 58\%, respectively); and low social and spiritual needs (58\% and $100 \%$, respectively). Briefly, $58 \%$ of patients have moderate health needs.

Table (4): shows that most of study patients ( $84 \%$ ) have high self-efficacy $\geq 50 \%$ with $($ Mean \pm SD, $74.80 \pm 26.95)$.

Table (5): shows that there is highly statistically significant negative correlation between health needs of the study patients and their self efficacy. 
Table (1): Distribution of the study patients according to their socio-demographic characteristics $(n=50)$

\begin{tabular}{|c|c|c|}
\hline Socio-demographic characteristics & No. & $\%$ \\
\hline $\begin{array}{c}\text { Gender } \\
\text { Male } \\
\text { Female }\end{array}$ & $\begin{array}{c}5 \\
45\end{array}$ & $\begin{array}{l}10.0 \\
90.0\end{array}$ \\
\hline $\begin{array}{l}\text { Age } \\
\begin{array}{l}20-<30 \\
30-<40 \\
40-<50 \\
50-<60 \\
\geq 60\end{array}\end{array}$ & $\begin{array}{c}5 \\
8 \\
14 \\
12 \\
11\end{array}$ & $\begin{array}{l}10.0 \\
16.0 \\
28.0 \\
24.0 \\
22.0\end{array}$ \\
\hline Mean \pm SD & \multicolumn{2}{|c|}{$47.96 \pm 11.31$} \\
\hline $\begin{array}{l}\text { Job } \\
\text { Officer } \\
\text { Laborer } \\
\text { Retired } \\
\text { Housewife }\end{array}$ & $\begin{array}{c}8 \\
6 \\
4 \\
32\end{array}$ & $\begin{array}{c}16.0 \\
12.0 \\
8.0 \\
64.0\end{array}$ \\
\hline $\begin{array}{l}\text { Education } \\
\text { Don't read \& don't write } \\
\text { Read \& write } \\
\text { Primary education } \\
\text { Secondary education } \\
\text { Institute } \\
\text { University } \\
\text { Post graduate }\end{array}$ & $\begin{array}{c}9 \\
10 \\
9 \\
18 \\
1 \\
2 \\
1\end{array}$ & $\begin{array}{c}18.0 \\
20.0 \\
18.0 \\
36.0 \\
2.0 \\
4.0 \\
2.0\end{array}$ \\
\hline $\begin{array}{l}\text { Marital status } \\
\text { Single } \\
\text { Married } \\
\text { Widowed } \\
\text { Divorced }\end{array}$ & $\begin{array}{c}1 \\
41 \\
7 \\
1\end{array}$ & $\begin{array}{c}2.0 \\
82.0 \\
14.0 \\
2.0\end{array}$ \\
\hline $\begin{array}{l}\text { Residence area } \\
\text { Urban } \\
\text { Rural }\end{array}$ & $\begin{array}{c}50 \\
0\end{array}$ & $\begin{array}{c}100.0 \\
0.0\end{array}$ \\
\hline $\begin{array}{l}\text { Family income } \\
\text { Enough } \\
\text { Not enough }\end{array}$ & $\begin{array}{l}17 \\
33\end{array}$ & $\begin{array}{l}34.0 \\
66.0\end{array}$ \\
\hline $\begin{array}{l}\text { Treatment payment system } \\
\text { Health insurance } \\
\text { Patient expense } \\
\text { Government expense }\end{array}$ & $\begin{array}{l}14 \\
20 \\
16\end{array}$ & $\begin{array}{l}28.0 \\
40.0 \\
32.0\end{array}$ \\
\hline
\end{tabular}


Table (2a): Distribution of the study patients according to their medical history $(\mathrm{n}=50)$

\begin{tabular}{|c|c|c|}
\hline Medical history & No. & $\%$ \\
\hline $\begin{array}{l}\text { Disease duration } \\
6 \text { months }-1 \text { year } \\
1 \text { year }>3 \text { years } \\
3 \text { years }-5 \text { years } \\
>5 \text { years }\end{array}$ & $\begin{array}{l}8 \\
2 \\
16 \\
24\end{array}$ & $\begin{array}{c}16.0 \\
4.0 \\
32.0 \\
48.0\end{array}$ \\
\hline $\begin{array}{l}\text { Detection of disease by } \\
\text { periodic checkup } \\
\text { suffering from symptoms }\end{array}$ & $\begin{array}{c}2 \\
48\end{array}$ & $\begin{array}{c}4.0 \\
96.0\end{array}$ \\
\hline $\begin{array}{l}\text { Suffering from other chronic diseases } \\
\text { No } \\
\text { Yes }\end{array}$ & $\begin{array}{l}18 \\
32\end{array}$ & $\begin{array}{l}36.0 \\
64.0\end{array}$ \\
\hline $\begin{array}{l}\text { If yes } \\
\text { Hypertension } \\
\text { Cardiovascular diseases } \\
\text { Diabetes mellitus } \\
\text { Thyroid diseases } \\
\text { Renal diseases } \\
\text { Liver diseases } \\
\text { Respiratory diseases } \\
\text { Rheumatic diseases } \\
\text { Osteoporosis } \\
\text { Lumbar disc prolapse } \\
\text { Glaucoma } \\
\text { Anemia } \\
\text { Hypotension }\end{array}$ & $\begin{array}{c}22 \\
6 \\
5 \\
1 \\
0 \\
5 \\
3 \\
1 \\
1 \\
4 \\
1 \\
1 \\
1\end{array}$ & $\begin{array}{c}68.8 \\
18.8 \\
15.6 \\
3.1 \\
0.0 \\
15.6 \\
9.4 \\
3.1 \\
3.1 \\
12.6 \\
3.1 \\
3.1 \\
3.1\end{array}$ \\
\hline $\begin{array}{l}\text { Rheumatoid treatment } \\
\text { Medications \&physiotherapy } \\
\text { Medications } \\
\text { Not comply treatment } \\
\end{array}$ & $\begin{array}{c}6 \\
43 \\
1 \\
\end{array}$ & $\begin{array}{c}12.0 \\
86.0 \\
2.0\end{array}$ \\
\hline $\begin{array}{l}\text { Are you adherent to medications } \\
\text { No } \\
\text { Yes }\end{array}$ & $\begin{array}{c}5 \\
45\end{array}$ & $\begin{array}{l}10.0 \\
90.0\end{array}$ \\
\hline $\begin{array}{l}\text { If no why: } \mathbf{n}=\mathbf{5} \\
\text { Neglect doses of medications } \\
\text { Need money } \\
\text { Lack of knowledge about importance of medications }\end{array}$ & $\begin{array}{l}2 \\
2 \\
1\end{array}$ & $\begin{array}{l}40.0 \\
40.0 \\
20.0\end{array}$ \\
\hline $\begin{array}{l}\text { Family history of disease } \\
\text { No } \\
\text { Yes }\end{array}$ & $\begin{array}{l}39 \\
11\end{array}$ & $\begin{array}{l}78.0 \\
22.0\end{array}$ \\
\hline $\begin{array}{l}\text { If yes who: } \mathbf{n = 1 1} \\
\text { First degree } \\
\text { Second degree } \\
\text { Third degree } \\
\text { Fourth degree }\end{array}$ & $\begin{array}{l}3 \\
4 \\
3 \\
1\end{array}$ & $\begin{array}{c}27.3 \\
36.4 \\
27.3 \\
9.1\end{array}$ \\
\hline Disease prognosis in family: $n=11$ & 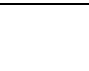 & \\
\hline
\end{tabular}


Improved

Complicated

Death

\begin{tabular}{l|c||}
9 & 81.8 \\
1 & 9.1 \\
1 & 9.1 \\
\hline
\end{tabular}

Table (2b): Distribution of the study patients according to their medical history $(n=50)$

\begin{tabular}{|c|c|c|}
\hline Medical history 2 & No. & $\%$ \\
\hline \multicolumn{3}{|l|}{ Articular manifestations } \\
\hline Joints pain & 50 & 100.0 \\
\hline Early morning stiffness & 34 & 68.0 \\
\hline Joints tender, warm and swollen & 45 & 90.0 \\
\hline Joints movement limitation & 48 & 96.0 \\
\hline Joints deformity & 13 & 26.0 \\
\hline \multicolumn{3}{|l|}{ Extra - articular manifestations } \\
\hline Chronic muscle ache & 26 & 52.0 \\
\hline Difficulty in performing activities of daily living & 42 & 84.0 \\
\hline Fatigue with minimum effort & 26 & 52.0 \\
\hline Dyspnea & 33 & 66.0 \\
\hline \multicolumn{3}{|l|}{ Medications side effects } \\
\hline Nausea & 3 & 6.0 \\
\hline Vomiting & 2 & 4.0 \\
\hline Heart burn & 25 & 50.0 \\
\hline Anorexia & 7 & 14.0 \\
\hline Weight gain & 17 & 34.0 \\
\hline Constipation & 11 & 22.0 \\
\hline Diarrhea & 2 & 4.0 \\
\hline Dysuria & 10 & 20.0 \\
\hline Hematuria & 0 & 0.0 \\
\hline Urinary retention & 1 & 2.0 \\
\hline Increased liver enzymes & 1 & 2.0 \\
\hline Leucopenia & 1 & 2.0 \\
\hline Нाताप & 1 & 2.0 \\
\hline
\end{tabular}


Table (3): Distribution of the study patients according to their health needs $(n=50)$

\begin{tabular}{|c|c|c|c|c|c|c|}
\hline \multirow[t]{2}{*}{ Health needs } & \multicolumn{2}{|c|}{$\begin{array}{c}\text { Low need } \\
<33.3 \%\end{array}$} & \multicolumn{2}{|c|}{$\begin{array}{c}\text { Moderate } \\
\mathbf{3 3 . 3}-\mathbf{6 6 . 6 \%}\end{array}$} & \multicolumn{2}{|c|}{$\begin{array}{c}\text { High need } \\
\geq 66.7\end{array}$} \\
\hline & No. & $\%$ & No. & $\%$ & No. & $\%$ \\
\hline Physical needs & 13 & 26.0 & 27 & 54.0 & 10 & 20.0 \\
\hline Rest and Sleep & 20 & 40.0 & 17 & 34.0 & 13 & 26.0 \\
\hline Eating & 26 & 52.0 & 13 & 26.0 & 11 & 22.0 \\
\hline Mobility & 21 & 42.0 & 20 & 40.0 & 9 & 18.0 \\
\hline Body Care "Personal hygiene" & 19 & 38.0 & 15 & 30.0 & 16 & 32.0 \\
\hline Wearing clothes "Dressing" & 17 & 34.0 & 15 & 30.0 & 18 & 36.0 \\
\hline Household chores "for females" $(n=45)$ & 12 & 26.7 & 19 & 42.2 & 14 & 31.1 \\
\hline Holding and Gripping "Hand Activities & 8 & 16.0 & 15 & 30.0 & 27 & 54.0 \\
\hline Work "for employed patients(n=14) & 8 & 57.1 & 6 & 42.9 & 0 & 0.0 \\
\hline Exercise & 6 & 12.0 & 16 & 32.0 & 28 & 56.0 \\
\hline Medications & 22 & 44.0 & 23 & 46.0 & 5 & 10.0 \\
\hline Sexual Relation $(\mathrm{n}=41)$ & 12 & 29.3 & 21 & 51.2 & 8 & 19.5 \\
\hline Psychological needs & 5 & 10.0 & 21 & 42.0 & 24 & 48.0 \\
\hline Social needs & 29 & 58.0 & 14 & 28.0 & 7 & 14.0 \\
\hline Spiritual needs & 50 & 100.0 & 0 & 0.0 & 0 & 0.0 \\
\hline Educational needs & 10 & 20.0 & 40 & 80.0 & 0 & 0.0 \\
\hline Overall needs & 14 & 28.0 & 29 & 58.0 & 7 & 14.0 \\
\hline
\end{tabular}

Table (4): Distribution of the study patients according to their self-efficacy $(n=50)$

\begin{tabular}{||c|c|c|}
\hline \multicolumn{1}{|c|}{ Self-efficacy } & No. & $\%$ \\
\hline Low self-efficacy $<50 \%$ & 8 & 16.0 \\
High self-efficacy $\geq 50 \%$ & 42 & 84.0 \\
\hline Min - Max & \multicolumn{2}{|c|}{$0.0-100.0$} \\
Mean \pm SD & $74.80 \pm 26.95$ \\
\hline
\end{tabular}


Table (5): Pearson coefficient correlation between health needs of the study patients and their self-efficacy.

\begin{tabular}{||c|c|c|}
\hline \multirow{2}{*}{ Items } & \multicolumn{2}{|c|}{ Total self-efficacy } \\
\cline { 2 - 3 } & $\mathbf{R}$ & $\mathbf{p}$ \\
\hline Total health needs & $-0.763^{*}$ & $<0.001^{*}$ \\
\hline
\end{tabular}

r: Pearson coefficient

*: Statistically significant at $\mathrm{p} \leq 0.05$

\section{DISCUSSION:}

The current study portrays that more than half of patients have physical needs. The highest physical needs in this study are in relation to holding and gripping "hand activities", as well as exercise. This concurs with (Poole, 2011) who mentioned that RA results in pain, deformities, weakness, and other impairments that affect the hands. Also, this supports the view of (Cooney et al., 2011) who demonstrated that RA patients do less exercise than their healthy counterparts, and that uncertainty about the benefits of exercise and appropriate type of it, deters many patients from exercising at all, which also prove the same in this study.

Almost half of patients have high psychological needs whereas they always experience mood swings which appear as anxiety, fear, sadness and the latter is considered an indicator for depression, as well as they sometimes feel distress without reason. From the viewpoint of the researcher, increased pain, fatigue, reduced healthrelated quality of life, increased physical disability and health care costs are considered as stress factors that may lead to psychological distress and in turn, a higher need for emotional support. An additional explanation is that physicians tend to objectify patients and focus only on the physical symptoms, hence negligence of psychological support. This suggests reinforcing the role of nurse in the provision of emotional support for RA patients.

This result coincides with (Kostova et al., 2014; Ahlstrand et al., 2012; Lack et al., 2011) who concluded that RA may have a powerful psychological impact, evoking a variety of negative thoughts and emotions that adversely affect wellbeing. 
Similarly, Cho et al. (2013); Mostafa \& Radwan. (2013); and Ho et al. (2011) demonstrated that depression and anxiety frequently occur in RA, and are significantly associated with poorer health-related quality of life and subsequently higher psychological needs.

The findings of this study show that more than half of patients have low social needs. This indicates that RA had less effect on patients' social life. A possible explanation is that RA patients adapt to balance their social roles, relationships and activities while contending with pain, fatigue and disability imposed by RA. This is broadly consistent with (Poh et al., 2015) who mentioned that social relationships and role balance are unaffected by RA and most patients still enjoy an active social life. On the contrary, Zuidema et al. (2015) and Feldthusen et al. (2013) found that the illness has a significant negative impact on role balance and social functioning.

Also, all of patients have low spiritual needs in the present study. This result disagrees with (Lin et al., 2011) who concluded that RA patients have a strong need for spiritual support.

The current study reveals that most of patients have educational needs, especially in areas of disease follow up, medications, treatment options, clinical manifestations and complications of disease. Similarly, Poh et al. (2015) mentioned that patients have inadequate information in these areas. As well, this result agrees with (Zuidema et al., 2015) who showed that RA patients have informational needs for various topics e.g. medications.

In the present study, most of patients have high self-efficacy. A possible explanation is that the chronic nature of RA and its related pain require patients to learn novel health behaviors to manage and adapt to their disease and as means of enhancing their self-efficacy.

The current study elicits that patients' self-efficacy is negatively correlated with their health needs. This finding coincides with (Barlow, 2013) who mentioned that greater levels of self-efficacy are typically associated with less psychological distress "less anxiety and depression", greater tolerance of pain and other symptoms, 
increased ability to cope, greater use of self-care activities, better physical functioning and hence lower health needs. This is also in accordance with (Sinikallio et al., 2014; Ahmed et al., 2012) who demonstrated that high self-efficacy consistently correlates with patients' functional ability and therefore, their health needs. Ahmed et al. 2012 added that strengthening self-efficacy results in improving functioning of RA patients and subsequently lowering health needs of these patients.

\section{CONCLUSION :-}

Based on the results of the present study, more than half of rheumatoid arthritis patients have health needs, although most of them have high self-efficacy. The highest needs are in relation to psychological needs, then physical needs, then educational needs, while the lowest needs are in relation to social and spiritual needs. Also, there is highly statistically significant negative correlation between health needs of rheumatoid arthritis patients and their self-efficacy.

\section{RECOMMENDATIONS:}

Based on the findings of the current study, the following recommendations are suggested: nurses should enhance health education programs provided to rheumatoid arthritis patients, including proper pain management strategies and techniques for overcoming physical limitations to help patients feel more in control of their pain and improve their physical functions, thereby reducing psychosocial distress. Family involvement in patient education should be strongly encouraged so that family members can better empathize and provide active support for the patients throughout their illness experience. Also, patient education materials should be redesigned to present more comprehensive information, including causes of rheumatoid arthritis, triggers of flare-ups, medication use and their side effects, as well self-management strategies.

Furthermore, nurses need to actively screen for patients at risk of psychological distress or depression and providing appropriate support for these patients such as empathic listening and validating their suffering, instead of focusing only on physical symptoms, to maintain their psychological health. Nurses can also conduct support groups for rheumatoid arthritis patients so that the latter can share 
their experiences and coping strategies, and gain confidence and self-efficacy from meeting other rheumatoid arthritis patients who are successfully coping with everyday life.

\section{REFERENCES:}

Ahlstrand, I., Björk, M., Thyberg, I., Börsbo, B., \& Falkmer, T. (2012). Pain and daily activities in rheumatoid arthritis. Disability and Rehabilitation, 34(15), 12451253.

Ahmed, S. T., Sobeih, H. S., \& Ahamed, N. G. (2012). Effect of Discharge Planning On Knowledge and Self-Efficacy of Patients with Rheumatoid Arthritis. Journal of American Science, 8(9), 7-15.

Almeida, M., Almeida, J., \& Bertolo, M. (2014). Demographic and clinical features of patients with rheumatoid arthritis in Piauí, Brazil - evaluation of 98 patients. Revista Brasileira de Reumatologia (English Edition), 54(5), 360-365.

Barlow, J. (2013). Self-efficacy in the context of rehabilitation. International Encyclopedia of Rehabilitaition.

Brand, C., Claydon-Platt, K., McColl, G., \& Bucknall, T. (2010). Meeting the needs of people diagnosed with rheumatoid arthritis: an analysis of patient-reported experience. Journal of Nursing and Healthcare of Chronic Illness, 2(1).

Carlsson, E., Berndtsson, I., Hallen, A., \& Lindholm, E. (2010). Concerns and quality of life before surgery and during the recovery period in patients with rectal cancer and an ostomy. Journal of Wound Ostomy Continence Nurse, 37(3), 654-661.

Cho, S. K., Kim, D., Jun, J. B., Bae, S. C., \& Sung, Y. K. (2013). Factors influencing quality of life (QOL) for Korean patients with rheumatoid arthritis (RA). Rheumatology international, 33(1), 93-102.

Cooney, J. K., Law, R. J., Matschke, V., Lemmey, A. B., Moore, J. P., Ahmad, Y., Jones, J. G., Maddison, P., \& Thom, J. M. (2011). Benefits of exercise in rheumatoid arthritis. Journal of Aging Research, 2011(2011), 1-14. 
Feldthusen, C., Björk, M., Forsblad-d'Elia, H., Mannerkorpi, K., \& University of Gothenburg Centre for Person-Centred Care (GPCC. (2013). Perception, consequences, communication, and strategies for handling fatigue in persons with rheumatoid arthritis of working age - a focus group study. Clinical Rheumatology, 32(5), 557-566.

Ferri, F. F. (2017). Ferri' s Clinical Advisor 2017: 5 Books in 1. Philadelphia: Elsevier, P. 1111.

Ho, R., Fu, E. H., Chua, A. N., Cheak, A. A., \& Mak, A. (2011). Clinical and psychosocial factors associated with depression and anxiety in Singaporean patients with rheumatoid arthritis. International Journal of Rheumatic Diseases, 14(1), 37-47.

Hurlbert, I. B. (2002). A cross sectional survey of self-reported quality of life in females and males with rheumatoid arthritis. Publihed master thesis. Calgary Un; Fac. Nursing, pp. 89-103

Kostova, Z., Caiata-Zufferey, M., \& Schulz, P. J. (2014). The process of acceptance among rheumatoid arthritis patients in Switzerland: A qualitative study. Pain Research and Management, 19(2), 61-68.

Lack, S., Noddings, R., \& Hewlett, S. (2011). Men's experiences of rheumatoid arthritis: An inductive thematic analysis. Musculoskeletal Care, 9(2), 102-112.

Larkin, L., \& Kennedy, N. (2014). Correlates of physical activity in adults with rheumatoid arthritis: a systematic review. Journal of Physical Activity and Health, 11(6), 1248-1261.

Lee, H. C., Tsai, Y. F., Luo, S. F., \& Tsay, P. K. (2010). Predictors of disability in Taiwanese patients with rheumatoid arthritis. Journal of Clinical Nursing, 19(21-22), 2989-2996.

Lesko, M., Young, M., \& Higham, R. (2010). Managing inflammatory arthritides: Role of the nurse practitioner and physician assistant. Journal of the American Academy of Nurse Practitioners, 22(7), 382-92. 
Lin, W. C., Gau, M. L., Lin, H. C., \& Lin, H. R. (2011). Spiritual well-being in patients with rheumatoid arthritis. Journal of Nursing Research, 19(1), 1-12.

Lorig, K., Chastain, R. L., Ung, E., Shoor, S., \& Holman, H. R.( 1989). Development and evaluation of a scale to measure self-efficacy in people with arthritis. Arthritis and Rheumatism, 32 (1), 37-44.

Mohamed, W. I. (2012). Concerns of patients with rheumatoid arthritis. Published master thesis. Alexandria Un; Fac. Nursing, pp. 30-34.

Mostafa, H., \& Radwan, A. (2013). The relationship between disease activity and depression in Egyptian patients with rheumatoid arthritis. The Egyptian Rheumatologist, 35(4), 193-199.

Poh, L. W., He, H. G., Lee, C. S. C., Cheung, P. P., \& Chan, W. (2015). An integrative review of experiences of patients with rheumatoid arthritis. International Nursing Review, 62(2), 231-247.

Poole, J. L. (2011). Measures of hand function: Arthritis Hand Function Test (AHFT), Australian Canadian Osteoarthritis Hand Index (AUSCAN), Cochin Hand Function Scale, Functional Index for Hand Osteoarthritis (FIHOA), Grip Ability Test (GAT), Jebsen Hand Function Test (JHFT), and Michigan Hand Outcomes Questionnaire (MHQ). Arthritis care \& research, 63(S11), S189-S199.

Primdahl, J., Wagner, L., \& Hørslev-Petersen, K. (2011). Self-Efficacy as an Outcome Measure and its Association with Physical Disease-Related Variables in Persons with Rheumatoid Arthritis: A Literature Review. Musculoskeletal Care, 9(3), $125-140$.

Sinikallio, S. H., Helminen, E. E., Valjakka, A. L., Väisänen-Rouvali, R. H., \& Arokoski, J. P. (2014). Multiple psychological factors are associated with poorer functioning in a sample of community-dwelling knee osteoarthritis patients. JCR: Journal of Clinical Rheumatology, 20(5), 261-267. 
Smolen, J. S., Aletaha, D., \& McInnes, I. B. (2016). Rheumatoid arthritis. The Lancet, 388(10055), 2023-2038.

Sperber, N., Hall, K. S., Allen, K., DeVellis, B. M., Lewis, M., \& Callahan, L. F. (2014). The role of symptoms and self-efficacy in predicting physical activity change among older adults with arthritis. Journal of Physical Activity and Health, 11(3).

Usenbo, A., Kramer, V., Young, T., \& Musekiwa, A. (2015). Prevalence of arthritis in Africa: A systematic review and meta-analysis. PloS one, 10(8), e0133858.

Zuidema, R. M., Repping-Wuts, H., Evers, A. W. M., Van Gaal, B. G. I., \& Van Achterberg, T. (2015). What do we know about rheumatoid arthritis patients' support needs for self-management? A scoping review. International Journal of Nursing Studies, 52(10), 1617-1624.

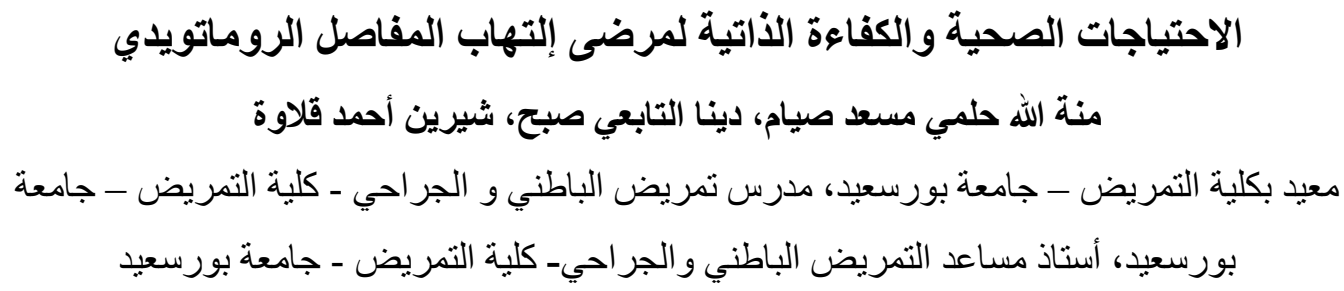

\section{الخـلاصـة}

مرض التهاب المفاصل الروماتويدي هو مرض مناعي مزمن بؤثر بشكل كبير علي صحة المرضى الجسدية

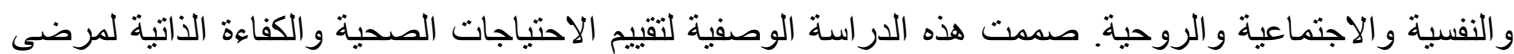
التهاب المفاصل الروماتويدي، وقد أجريت هذه الدر اسة على 50مريض من العيادات الخارجية لأمر اض الروماتيزم بالمستشفيات التابعة لوزارة الصحة بمحافظة بورسعيد (مستشفى بورسعيد العام ومستشفى بور فؤاد العام). تم

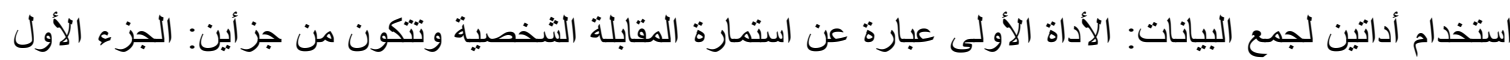
يتضمن الخصائص الديمو غر افية و التاريخ الطبي للمريض و الجزء الثاني لتقييم الاحتياجات الصحية لمرضى التهاب المفاصل الروماتويدي أما الأداة الثانية عبارة عن مقياس لتقييم الكفاءة الذاتية لهؤلاء المرضى. أظهرت نتائج الدراسة أن أكثر من نصف المرضى لديهم احتياجات صحية بالر غم من أن معظمه ذو كفاءة ذاتية عالية للمرض. تتمثل الاحتياجات الأعلى للمرضى في الاحتياجات النفسية ثم الجسدية ثم التعليمية بينما تتمثل الاحتياجات الأقل في

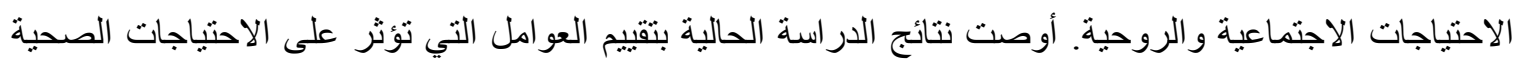
و الكفاءة الذاتية لمرضى التهاب المفاصل الروماتويدي.

الكلمات المرشدة: الاحتياجات الصحية، المرضى، التهاب المفاصل الروماتويدي، الكفاءة الذاتية. 